Марија М. Булатовић

Универзитет у Београду

Филолошки факултет

Студенткиња докторских студија

bmarija90@gmail.com doi: 10.19090/zjik.2018.27-38

UDK 811.111.09

прегледни рад

\title{
БЕСЕДА КАО ТЕЛО: О ЕСТЕТИЦИ ТЕКСТУАЛНОГ ЗАДОВОЉСТВА ${ }^{1}$
}

САЖЕТАК: Пошавши од Сократове тврдње у Платоновом дијалогу Федар или о Лепоти, која гласи да је свака беседа састављена као живо биће, чија је целовитост, функција и естетска димензија представљена кроз органицистичку метафору тела, уочава се веза са савременим књижевно-теоријским поставкама о узајамном еросу текста и читаоца, односно реципијента. Сократовска представа беседе, односно текста, као тела пронашла је своје потоње утемељење у каснијим, нешто измењеним, књижевним теоријама, као што је концепт текста Ролана Барта (Roland Barthes) као par excellence еротског тела у којем се, као у наслади, ужива. Преко обједињујуће идеје о текстуалној телесности, у предстојећем раду се, кроз феномен ероса текста, покушава објаснити однос текста и реципијента путем довођења у везу Мерло-Понтијеве (Maurice Merleau-Ponty) идеје о феноменологији речи и статуса израза и Бартове идеје о тексту као задовољственом објекту. Циљ рада јесте да се путем Мерло-Понтијевих импликација о корпореалности свести и интенционалности тела тумаченим у блиској спрези са Бартовом теоријском позицијом о тексту као фетишу који нас жели, заводи и обистињује се као „списак језичких ватри” дође до плодоносног разумевања чина читања/слушања као својеврсног задовољственог доживљаја, односно - да се, у комуникацији Мерло-Понтијеве и Бартове теоријске позиције, покуша разумети телесна структура беседе, као и однос говорника, естетске ауре тела беседе и њеног ефекта на публикум.

Кључне речи: беседа, текст, тело, Ролан Барт, Морис Мерло-Понти

\footnotetext{
${ }^{1}$ Овај рад излаган је у скраћеној верзији на научном скупу са међународним учешћем Традиционална естетска култура 12: Беседа који је одржан у Нишу, 10. новембра 2017. године у организацији Центра за научноистраживачки рад САНУ и Универзитета у Нишу и Факултета уметности у Нишу.
} 


\section{1. КЊИЖЕВНОСТ У СВЕТЛУ ФИЛОЗОФСКЕ АНАЛИЗЕ: ЗАШТО ФЕНОМЕНОЛОГИЈА?}

Тумачити књижевност у светлу филозофије, што притом није филозофска критика схваћена као спољашњи приступ делу или „црпљење” идејне интелигибилности текста, односно парцијална рефлексија о књижевном делу, која би уосталом била само његово „осиромашење”, чини се апсолутно легитимним поступком. Док је Платон, свестан психагошке снаге песничког дела, подредио песништво истинском бављењу филозофијом, а у десетој књизи Државе чак и прогнао песничко умеће из грчког полиса, Аристотелова умеренија позиција, када је реч о схватању уметности, чини се и прикладнијом. У Поетици за Аристотела песништво је довољно „филозофско” да би било схваћено као универзална и насушна истина:

Зато је пјесничко умијеће филозофскије од повијести и треба га схватити озбиљније од ње. Пјесништво, наиме, говори више оно што је опћенито, а повијест оно што је појединачно. Опћенито значи каква ће се врста ствари десити човјеку одређене врсте да говори или ради по вјеројатности или нужности, а за тим иде пјесничко умијеће надијевајући имена... (Аристотел 1983: 24).

Ако разумемо да се фундаментална филозофска питања - онтолошка, епистемолошка, етичка и естетичка - преиспитују из позиције филозофског става, који стоји насупрот природном и наивном ставу света живота (Lebenswelt), ${ }^{2}$ отуда постаје евидентно да кључна филозофска питања јесу управо она која, као читаоци, у једном дијалектичком односу са текстом, постављамо песничком делу као естетском простору свођења на суштинско, из позиције запитаности, односно специфично критичког става. Отуда, песништво, фундаментална сфера поетских чињеница и феномена, може бити схваћено и као „несистематичан одговор на питања која су уједно проблеми филозофије” (Константиновић 1969: 92). Песничко дело својом специфичном онтологијом и формом подстиче на анализу, критику, спекулацију и

2 Хусерл развија овај термин у незавршеној студији Криза европских наука $и$ трансиендентална феноменологија (Die Krisis der europäischen Wissenschaften und die transzendentale Phänomenologie; 1936). Хусерл такође разликује два става из којих се, у сусрету субјективног и објективног, догађа спознаја: природни став (natürliche Einstellung), усмерен свету живота, и филозофски став (philosophische Einstellung) који захтева растерећен, чист, трансцендентални его. 
интерпретацију и самим тим потврђује оправданост употребе филозофских „алата” у уметничком делу, притом враћајући љубав према слову, logos-у, својој изворној суштини - љубави према мудрости, знању и словесности, мишљењу мишљења. И поред својих евентуалних недостатака и недовољно систематичне и дефинисане јединствене методе (а уосталом такво је и песничко дело), феноменолошка анализа књижевног дела указује се подесном, јер представља враћање феноменима, односно „самим стварима”, умеће сагледавања суштине у саодносу предмета и опажајне свести која се брине о значењу, смислу и чистим есенцијама на путу да демистификује non so che уметничког дела. Надаље, поред изразите упућености на феномене језика, феноменологија је нарочито заслужна за развијање концепта тела и телесности, особито у филозофији Мориса Мерло-Понтија (Maurice MerleauPonty), француског филозофа феноменолошке оријентације, чије су премисе нашле одјека у потоњим теоријама о уметности, на пример, у књижевној теорији његовог савременика и, једно време, суграђанина - Ролана Барта (Roland Barthes), теоретичара и семиотичара постструктуралистичке оријентације. Обједињујући Мерло-Понтијев феноменолошки концепт теласубјекта и Бартов концепт текста-тела, можемо покушати да објаснимо споменуто non so que телесно складног, формално и садржински, и естетски допадљивог говора - беседе. Довођењем филозофско-феноменолошке позиције Мориса Мерло-Понтија у близак дијалог са књижевно-теоријским ставовима Ролана Барта, путем феномена тела, испитује се и постструктуралистичка перспектива феноменолошког дискурса кроз њихову заједничку оријентацију на језик. Кроз Мерло-Понтијеву феноменологију речи и статуса израза и Бартову идеју о наслади у тексту као еротском телу, отвара се тема постојања ероса самог текста, љубави према читању/ слушању, односно естетске ауре говора и његовог психагошког дејства на публикум. Рад показује да се Бартове теоријске (естетичке) позиције могу, и више него што је очито, читати у синергији са Мерло-Понтијевим филозофским ставовима, као и да се у таквом методолошком луку може плодоносно интерпретирати појам и жанр беседе.

\section{2. СТИЛ ЈЕ ТЕЛО СА̂MО}

Каже се да феноменологија̂ има онолико колико има феноменолога, односно да су Хусерлове (Edmund Husserl) поставке трансценденталне феноменологије значајно модификовали и, на свој начин, интерпретирали његови настављачи и да, управо, у тим прилозима и замеркама Хусерловој 
недовољно конзистентној мисли лежи вредност феноменолошког метода. Мерло-Понти одвојио се од Хусерлових поставки које се тичу трансценденталног ега ${ }^{3}$ као a priori ванискуственог услова сазнања и отуда је, поред Хајдегера (Martin Heidegger), Сартра (Jean-Paul Sartre), Левинаса (Emmanuel Levinas), у историји филозофије сврстан у егзистенцијалне феноменологе. Хусерлову девизу „сва свест јесте свест о нечему (предмету)” Мерло-Понти замењује крилатицом да је „сва свест par excellence перцептуална”, а тело, у маниру дескриптивне психологије, поставља као fons et origo сазнања света. Тело као протежна ствар и свест јесу нераскидиво повезани, јер тело и опажај функционишу једино у синергији, на исти начин као што су мишљење и говор нераздвојиви. ${ }^{4}$ Мерло-Понти очито превазилази картезијански јаз, декартовску традицију мишљења која постулира разлику између свести која опажа (res cogitans) и перцепиране твари (res extensa), доводећи у питање Хусерлову дистинкцију поеsis-noета, разлику између чина свести и објекта свести. Доживљај сопственог тела открива нам онтолошку двосмисленост: тело не доживљавамо као било коју твар у с-твар-ности, већ је тело и надређени и подређени, онај који мисли и оно о коме/ чему се мисли, односно, уједно и тело у физичком смислу и мисао о телу. ${ }^{5}$ Већ је Хусерл, назирући проблем другога и интерсубјективности у трансценденталној феноменологији, начинио разлику између тела као корпуса, објекта међу другим објектима, и тела као психофизичког збивања у чијем се средишту налази „ја”, его. Међутим, Мерло-Понти истиче значај тела схваћеног као израз и реч, јер субјект који говори, из самог себе, актима конституисања, производи смисао и отвара се према себи, а онда и према свету и другоме. За

${ }^{3}$ Кантов појам који је Хусерл преузео. Међутим, има читања која тврде да је на Хусерла знатно више у том погледу утицао Наторп (Paul Gerhard Natorp). 3a више видети: Luft, Sebastian, Subjectivity and Lifeworld in Transcendental Phenomenology, Nothwestern University Press, Evanston, Illinois, 2011: 241.

4 Како тврди Мерло-Понти, чак и мисли неизговорене гласно одговарају „унутрашњем” говору, односно да мисао и не постоји изван света и речи (1978: 198). Више о томе видети: Phillip J. Walsh. 2017. „The Sound of Silence: Merleau-Ponty on Conscious Thought", European Journal of Philosophy Vol 25, Issue 2: 312-335.

5 Тело је уједно и субјект и објект и управо на тој дијалектици активности и пасивности Мишел Фуко (Michel Foucauld) hе у Надзирању и кажњавању (Surveiller et punir; 1975) развити своје концепте потчињавања и постајања субјектом (assujettissement et subjectivation). Међутим, за разлику од Мерло-Понтијевог схватања, Фукоов субјект понаша се као предмет науке који се потчињава њеним законима и праксама, а не као да је проистекао из њих самих. 
Мерло-Понтија тело није скуп честица, нити преплитање одређених процеса једном за свагда, већ је тело мисаони израз и мисаони израз јесте тело - смисао се лучи у таквој врсти дијалектике:

Оно [Тело] није скуп честица од којих би свака постојала по себи, нити пак преплитање одређених процеса једном засвагда - оно није тамо где је, оно није оно што је - пошто га видимо како само по себи лучи „смисао” који му не долази ни одакле, како га пројектује на своју материјалну околину и саопштава другим отеловљеним субјектима. Увек се примећивало да кретња или реч преображавају тело, али се задовољавало тиме да се каже да оне развијају или испољавају једну другу моћ, мисао или душу. Није се увиђало да тело, да би могло да их изрази, мора у крајњој анализи постати мисао или намера коју нам оно значи (1978: 339-340).

Тело и реч ухваћени су у дијалектички обрт: реч је нераздвојива од језичког света, а тело је уроњено у језик. Специфичан вид испољавања језика путем говора субјекта представља истрајавање света и „таложења интерсубјективне тековине" (Мерло-Понти 1978: 321). Све се догађа као да намера мог тела почива у другом и обрнуто, јер само својим телом ,ја разумем другог, као што тек својим телом опажам ствари" (Мерло-Понти 1978: 327) на тај начин успостављајући корпореалност свести као интенционалност тела. Интенционалност тела као корпореалност свести јесте идеја која је нарочито значајна у разумевању естетске димензије беседе.

Очито је да Мерло-Понти не говори о телу у уским оквирима, ${ }^{6}$ телу као корпусу, и да реч и израз, у ствари, постају тело мисли и њен амблем на сличан начин као што је тело говорећег субјекта израз његовог говора који има функцију да егзекутира, а не да преводи унапред већ створену мисао. Именовање уједно је и препознавање (Мерло-Понти 1978: 318). За МерлоПонтија речи не могу бити „тврђаве мисли” (1978: 323), јер је веза означеног и означитеља конвенционална, али та веза испод појмовног крије једно егзистенцијално значење. Реч изражава увек нешто више од свог основног

6 „Ја себе замишљам према речи као што је моја рука према месту мог тела које тичем прстом, реч је на извесном месту мога језичког света, она је део моје опреме, ја имам само један начин да је себи представим, то је да је изговорим, као што и уметник има само један начин да себи представи дело на коме ради: ваља да га створи" (Мерло Понти 1978: 321). 
значења (Хартман 2004: 290). Отуда, сматра Мерло-Понти, смисао књижевног дела није појмовни смисао речи колико је то „мисао у говору” (1978: 320) коју ratio не може одгонетнути - реч је о својеврсној надмоћи, „преимућству ума” (Мерло-Понти 1978: 332). Бесеђење, читање или писање не представља пуко средство комуникације изван субјекта који говори/ пише или субјекта који слуша/ чита, већ је реч о позицији субјекта у свету његових значења (МерлоПонти 1978: 335). Говор постаје израз тела-субјекта, стил бивања у свету, као и стил изражавања у тексту/ говору. Тело постаје место стила.

\section{3. ТЕЛО И ТЕКСТ: ЕСТЕТСКА БИЋА}

Сличност Мерло-Понтијевом размишљању о узајамности мисли, говора и тела проналазимо у теорији Ролана Барта. С обзиром на то да се у Бартовој мисли може пронаћи идеја читања живота као текста који производи задовољство (Gil 2015: 37), упоредба Бартовог концепта тела са МерлоПонтијевим органистичким концептом чини се легитимном. Деконструисање „институисане” речи и уочавање етимолошко-егзистенцијалне везе између речи и унутар ње саме јесте уједно и задатак постструктуралиста које поједини теоретичари називају и постфеноменолозима. Барт се језички игра и постфеноменолошки упућује на идеју интенционалности тела и његовог „тобожњег ћутања као брујања речи” (Мерло-Понти 1978: 324): „Могу да учиним све са својим говором, али не и са својим телом. Што говором скривам, тело показује" (Барт 2011: 67). Говорена реч, односно говор, тврди Мерло-Понти, јесте гест чије је значење свет, односно чије се значење разуме у пресеку интенција онога који слуша и онога који говори (Мерло-Понти 1978: 199). Смисао геста, односно интенционалности тела током беседе, не може се откривати интелектуалистички или тумачити као физички (епи)феномен. Говорена реч је гест који се разуме на пресеку интелектуалног и моторичког и јасно је да „телесно збивање” и говор прате једно друго. Израз целог тела беседника очитује његову говорну интенцију, као и интенционални предмет (Мерло-Понти 1978: 495-496).

Барт развија концепт текстуалног задовољства повезујући текст, тело и еротско. Идеју о тексту као телу, односно о органској форми дела, проналазимо још у Платоновим списима, у Федру, где Сократ говори о лепој беседи као о живом бићу, односно прикладном и усклађеном телу и његовим 
деловима. ${ }^{7}$ За Барта прави предмет биографеме као најмање јединице биографије јесте тело, док је биографија прича фрагментизованог тела (Gil 2015:40). Међутим, Ролан Барт у Задовољству у тексту (Le plaisir du texte; 1973) говори о тексту као о еротском телу насладе са својим стилски осетљивим зонама текстуалне ексцитације. ${ }^{8}$ Простор насладе јесте par excellence естетски простор или, како је Валери (Paul Valéry) рекао „естетски бескрај” (l'infini esthétique). ${ }^{9}$ Текст је „бесконачно језика” - имагинаријуми језика (Барт 2010: 120), чист семиозис који чини да књижевност значи, док је књижевност схваћена као коначни свет - „скуп ефеката са коначном тежњом” (Валери 1980: 351). У том смислу, за Барта текст представља „отворени списак језичких ватри” (2010: 108), „моћан млаз речи” који рањава или заводи (Барт 2010: 122-124), фетишистички мами:

Текст је људског обличја, фигура је, анаграм тела? Да, али нашег еротског тела. Задовољство у тексту било би несводљиво на његово граматичарско (фенотекстуално) функционисање, као што је задовољство тела несводљиво на физиолошку потребу (2010: 108).

Као што у Мерло-Понтијевом концепту тела сексуалност постоји као својеврсна „атмосфера” која зрачи, интегрални део егзистенције, тако је и феномен еротског као привилеговани знак нужан у бартовској концепцији текста као тела, што додатно указује на сличност двеју позиција. Барт, као и Мерло-Понти који говори о употреби тела које трансцендира чисте биолошке оквире, не види тело искључиво као архетипски корелат души. Међутим, из претходног фрагмента можемо закључити да Барт, приписујући текстуалном телу специфичне еротске функције, такође не види еротизам као пуки анимални ужитак, већ, у батајевском маниру, као еротизацију - производњу еротичног с пуном свешћу о таквом чину. Овако схваћен текст Барт разуме као ткање које је у сталном настајању, износећи једну генеративну идеју при чему

7 Више о тој идеји видети: Платон, Федар или о лепоти, Народна књига - Алфа, Београд, 1996.

${ }^{8}$ О сексуалности тела говори и Мерло-Понти, али у контексту интенционалности, односно еротске тежње/ интенције према другом. Но, свакако, Мерло-Понти тумачи уметност као живо биће, односно у контексту органистичке естетике.

${ }^{9}$ Пол Валери (Paul Valéry) у свом есеју „Естетички бескрај” („L’infini esthétique”, 1934) прави разлику између ефеката са коначном тежњом који чине поредак практичних ствари и ефеката са бесконачном тежњом који чине поредак естетичких ствари и досежу максимум слободе - бескрај. Вид, додир, чула мириса и слуха, кретање и говор образују скуп ефеката с бесконачном тежњом. 
се читалац и са̂м ослобађа у таквој текстури и успоставља близак и значајно уживалачки однос са њом (Барт 2010: 142). Однос читаоца/ слушаоца и текста није картезијанска релација субјект-објект, већ одслик феноменолошке везе говора који је израз тела и тела које је део физичке стварности и језичког света: „Није више реч о томе да се у читању света и субјекта нађу опозиције, него - преливања, задирања, бекства, исклизнућа, премештања и излетања" (Барт 1992: 82).

Задовољство читања/ слушања очито је у спрези са сазнајнољубопитљивим импулсом нашег бића и интереса за догађај, причу и демистификацију, за праћење онога што се дешава и разоткривање онога што се скрива. Разоткривање догађајног слоја постаје еквивалент разодевању тела, а према Барту, најеротичније место на телу јесте оно где се одећа разгрнула (2010: 103). Међутим, следи да потпуно „разодевен” текст губи у потпуности набој језичког узбуђења, а интерес за пуки догађајни ниво наратива драстично промашује и заобилази суштински текстуални ужитак који почива у феноменима. Разликујући текстове задовољства (plaisir) који представљају лагодну праксу читања и текстове насладе (jouissance) који уздрмавају и доводе у кризу субјекта и његов језички свет, при чему се задовољство види као мала наслада, Барт простор насладе доводи у уску везу са жељом (désir), што оправда употребу Лаканових (Jacques Lacan) термина. ${ }^{10}$ Ерос текста као симптом задовољства у тексту долази управо од текстуалне прожетости жељом (désir), и то двоструком - физичком и духовном. Текст заводи читаоца, говорећи му кроз језик да га жели, док читалац, у фетишистичком односу, помно истражује текстуално тело „прождирући” 11 речи и реченице. Узбуђење долази од активности дискурса текста и у његовом позиву „желим те”, док читалац, с друге стране, у речи, мисли о говору, „умотава прочитано” (Барт 2011: 96). Реч је, дакле, о двоструком телесном контакту: „Језик је кожа: трљам свој језик о другога. То је као да имам речи уместо прстију, или прсте на крајевима својих речи. Језик ми подрхтава од жеље” (Барт 2011: 96).

Као што се посматра тело другог, тако се „истражује” и текст у жељи да се сазна шта је изнутра, да се допре до скривене суштине „као да је

\footnotetext{
${ }^{10}$ Барт прави дистинкцију између задовољства и насладе управо због многозначности речи задовољство у француском језику. За нас у овом тексту та дистинкција неће бити од кључне важности.

${ }^{11}$ Намерна употреба терминологије хране у блиској спрези са телом и телесношћу.
} 
механички узрок моје жеље у телу наспрам мене (налик сам оној деци која растуре часовник не би ли сазнала шта је то време)" (Барт 2011: 94). Перцепција за Мерло-Понтија крије једну дискретнију структуру - еротичку (1978: 171). Таква еротичка перцепција дешава се у свету, а не у свести с обзиром на то да једно тело смера на друго тело, на cogitatum. Мерло-Понти наводи пример девојке која престаје да спава, једе и говори након мајчине забране да се састаје са младићем којег воли (1978: 175). Губитак говора и престанак уношења хране указује на одбијање живота и коегзистенције: „гутање симболизира покрет егзистенције који пушта да кроза њ пролазе догађаји и асимилира их; болесница, дословце, не може „прогутати” забрану која јој је наметнута (Мерло-Понти 1978: 175). Читање/ слушање текста „гутањем” речи и реченица не симболише само еротичку структуру егзистенције, већ и текста прожетог жељом као привилегованим знаком те еротичке структуре, односно текстуре.

Вољено тело које помно посматрамо за нас је атопијско, јер се не да̂ сврстати нигде, и оно за нас постаје јединствено. Тако третирамо и текст који и сам, донекле, атопија, ма колико био снажан контакт са друштвеном стварношћу, или наткриљена сенка идеологије, текст нам нуди свет sui generis продукујући „стање” које је уистину искључено и мирно (Барт 2010: 118), односно беседу која нас „увлачи” у своје време-место:

Беседник не мисли пре беседе, па чак ни за време беседе, његова беседа је његова мисао. Исто тако, слушалац не схвата за време беседе знакове. „Мисао” беседника је празна за време док он беседи, и, док читамо неки текст пред собом, ако је изражавање успешно, ми немамо неку мисао изван самог текста, речи заузимају читав наш дух, оне тачно испуњавају наше ишчекивање и ми осећамо потребу говора, али ми нисмо у стању да га предвидимо и он нас обузима. Крај говора или текста биће крај очарања (Мерло-Понти, 1978: 320).

Успешно изражена беседа „потчињава”, односно опчињава, и беседника и слушаоца, усмерених на идеје које изражава текст. Интендираност на феномене и њихова реконституција дешава се и на нивоу свести публикума у којој се стварају унутрашње слике - речи и фантазми који одјекују њом. Барт сматра да је одјек (retentissement) темељни модус љубавне субјективности при 
чему одређена мисао резонира телом субјекта/ читаоца. ${ }^{12}$ Иако је данас у теорији књижевности неприхватљива идеја пројектовања читаоца у лик или било какав аутоскопски вид уплива у фикционални свет књижевности и текста, читање се ипак мора поставити на један слободан пут у којем је читалац субјект до краја, а читање апсолутно поље субјективности (Барт 1999: 215). То не значи да треба негирати и апсолутно релативизовати текст, али треба допустити нашем унутарњем телу и интуитивној способности која је изван разума да му „приђе”:

У мени одјекује оно што својим телом доживљавам: нешто оштро и танано одједном буди то тело које је у међувремену било клонуло у свом разумском познавању опште ситуације: реч, слика, мисао делују попут ударца корбачем. (Барт 2011: 231).

Током говора тело доживљава својеврсну трансфигурацију јер оно само постаје мисао, односно реч. У наведеном одломку субјект доживљава говор као резонирање могуће вербалне слике, међутим Мерло-Понти оспорава теорију вербалне слике наговештавајући да је вербална слика само „омот истинског именовања" (1978: 191), што наслућује и говорни субјект фрагмента. Одиста, субјект не дефинише јасно корбач говора који буди клонуло слушалачко тело, при чему се тело интерпретира у мерлопонтијевском кључу, односно као егзистенција која у својој перцептивној синтези разуме гестове, то јест говор другога. Такође, Барт поетично у фрагменту сажима суштину естетског доживљаја који се преноси управо путем тела, с обзиром да је тело „спроводник” жеље. И формално и садржински Барт истиче да су та „мала задовољства” умножена места љубави, еротско текста и уједно естетска димензија или аура беседе. Та аура беседе, коју више него иједан други облик текста у жанровском смислу, карактерише hic et nunc, „овде и сада” које нема историјску, време-простор димензију, већ, деиктички посматрано - снажно драмску, позоришну. Беседа, као и тело које има своју „овде и сада” просторно-временску структуру, прави је лингвистички гест који нужно има телесно обличје у једној синтезној форми мерло-понтијевске и бартовске теоријске позиције.

\footnotetext{
12 Упућујем на Бартову студију из 1977. године насловљену Фрагменти љубавног дискурса (Les fragments d'un discours amoreux).
} 
Своје психагошко својство беседа дугује узајамном односу тела и говора, односно тела-у-говору и говора-у-телу, као и контакту са светом. Самим тим, беседа и сама постаје тело, не само захваљујући беседнику који говори, јер бивајући (изговорена) мисао, беседа, попут живог бића, има par excellence телесно-еротичку структуру. Чим се човек служи говором ради успостављања живог односа са самим собом или са себи сличнима, „говор више није инструмент, није средство, он је испољавање, откривање присног бића и психичке везе која нас спаја са светом и са нама сличнима" (МерлоПонти 1978: 338). Беседа, као и тело, постаје интерсубјективна и интенционална - упућена слушалачком телу. Отуда, хедонистичко преливање обиља текста, које представља уживалачки аспект језика, проистиче из његове производње еротичног. Еротизација се остварује посредством жеље испољавањем једног присног, разодевеног бића које је, ништа друго до, естетско биће у пољу ефеката са бесконачном тежњом. Такво естетско биће може бити произведено од стране бића које је уједно и тело и дух, отворене перцепције и отворено ка стварању. Следи да се у таквој дијалектици феноменалног тела, како га формулише Мерло-Понти, и Бартовог текста-тела, чији је кључни појам еротско, рађа - естетско, односно специфична естетска димензија задовољственог у тексту.

\section{ЛИТЕРАТУРА}

Аристотел. 1983. O пјесничком умијећу, превео и приредио Здеслав Дукат. Загреб: Аугуст Цесарец.

Барт, Ролан. 2010. Задовољство у тексту и варијащије у писму, превео Јовица Аћин. Београд: Службени гласник.

Барт, Ролан. 1999. „О читању”. http://fabrikaknjiga.co.rs/rec/55/55.pdf (01. 10. 2017)

Барт, Ролан. 2011. Фрагменти љубавног дискурса, превод с француског Александар Милетић. Лозница: Карпос.

Барт, Ролан. 1992. Ролан Барт по Ролану Барту, превео М. Радовић. Нови Сад: Светови.

Валери, Пол. 1980. Песничко искуство. Београд: Просвета.

Gil, Marie. 2015. „Roland Barthes: Life as Text”. Translated by Sam Ferguson. Barthes Studies 1: 35-60.

Константиновић, Зоран. 1969. Феноменолошки приступ књижевном делу. Београд: Просвета. 
Luft, Sebastian. 2011. Subjectivity and Lifeworld in Transcendental Phenomenology. Evanston, Illinois: Nothwestern University Press.

Мерло-Понти, Морис. 1978. Феноменологија периепиије, превео с француског Анђелко Хабазин. Сарајево: „Веселин Маслеша”.

Платон. 1957. Држава. Београд: Култура.

Платон. 1996. Федар или о лепоти. Београд: Народна књига - Алфа.

Фуко, Мишел. 1997. Надзирати и кажњавати, превод Ана Јовановић.

Сремски Карловци: Издавачка књижарница Зорана Стојановића.

Хартман, Николај. 2004. Естетика, превео др Милан Дамњановић. Београд: Дерета.

Walsh, Phillip J. 2017. „The Sound of Silence: Merleau-Ponty on Conscious Thought". European Journal of Philosophy Vol 25, Issue 2: 312-335.

Marija M. Bulatović

\section{ORATION AS A BODY: ON THE AESTHETICS OF TEXTUAL PLEASURE}

\section{Summary}

Starting from Socrates' claim in Plato's dialogue Phaedrus, which states that each oration is composed as a living being whose integrity, function and aesthetic dimension are represented through an organicistic metaphor of the body, we come to the contemporary literarytheoretical postulates on the liaisons of eros of the text and recipient. Socrates' concept of the oration, i.e. text, as a textual body found its later foundation in literary theories, significantly changed, such as the notion of Roland Barthes on the text as erotic body par excellence in which, as in enjoyment (jouissance), we take delight. Through the unifying idea of textuality and the phenomenon of eros, the essay argues the dialectics between the text and the recipient by intertwining Merleau-Ponty's idea of the phenomenology of the word and the expression status and Barthes' idea of the text as a satisfying object. The aim of this paper is to reveal a fruitful understanding of the reading/listening act as a kind of satisfying sensation through Merleau-Ponty's implications of the corporeality of the consciousness and the intentionality of the body, interpreted in close connection with Barthes' theoretical position on the text as a fetish which allures, seduces and becomes an "open list of the fire language". The dialogue between Merleau-Ponty's and Barthes' theoretical position will help us understand the corporeal structure of the oration as well as the relation between the orator, the aesthetic aura of the body of oration and its effects on the audience.

Key words: oration, text, body, Roland Barthes, Maurice Merleau-Ponty 